\title{
A New Species of Pachysentis Meyer, 1931 (Acanthocephala: Oligacanthorhynchidae) in the Brown-Nosed Coati Nasua nasua (Carnivora: Procyonidae) from Brazil, with Notes on the Genus and a Key to Species
}

\author{
Ana Paula N. Gomes ${ }^{1,2}$. Omar M. Amin ${ }^{3}$. Natalie Olifiers ${ }^{4} \cdot$ Rita de Cassia Bianchi ${ }^{5}$. Joyce G. R. Souza ${ }^{1}$. \\ Helene S. Barbosa ${ }^{6} \cdot$ Arnaldo Maldonado Jr. $^{1}$
}

Received: 7 November 2018 / Accepted: 6 May 2019 / Published online: 8 July 2019

(c) The Author(s) 2019

\begin{abstract}
Introduction Pachysentis comprises 10 species, which have been reported parasitizing mammals in Africa and the American continent. However, species of Pachysentis have not been described in brow-nosed coatis. Pachysentis lauroi n. sp. (Oligacanthorhynchidae: Acanthocephala) is described from the brown-nosed coati Nasua nasua (Linnaeus, 1766) Storr, 1780 (Procyonidae: Carnivora) in the Brazilian Pantanal wetlands of the Mato Grosso do Sul State, Brazil.

Methods Specimens were studied using light and scanning electron microscopy.

Result The new species is distinguished from other species of Pachysentis by the number of hooks in each longitudinal row (12 rows of 4 hooks, total of 48 hooks), presence of barbs on all hooks, and the organization of the cement glands. Notes on the genus Pachysentis [14] and a key to its species are provided. Critical comments on some species with a dubious diagnosis and questionable or missed key taxonomic characteristics are also reviewed. We also discuss the zoogeography of the members of the genus.
\end{abstract}

Keywords Acanthocephala $\cdot$ Pachysentis lauroi n. sp. $\cdot$ Key to species $\cdot$ Carnivore $\cdot$ Mato Grosso do Sul $\cdot$ Brazil

\section{Introduction}

Pachysentis [14] comprises 10 species, which have been reported parasitizing mammals in Africa and the American

Arnaldo Maldonado Jr. maldonad@ioc.fiocruz.br

1 Laboratório de Biologia e Parasitologia de Mamíferos Silvestre Reservatório, Instituto Oswaldo Cruz, Fundação Oswaldo Cruz, Avenida Brasil, 4365 Manguinhos, Rio de Janeiro, RJ 21045-900, Brazil

2 Pós Graduação em Biologia Parasitária, Instituto Oswaldo Cruz, Fundação Oswaldo Cruz, Rio de Janeiro, Brazil

3 Institute of Parasitic Diseases, 11445 E. Via Linda 2-419, Scottsdale, AZ 85259, USA

4 Universidade Veiga de Almeida, Rua Ibituruna, 108 Maracanã, Rio de Janeiro, RJ 20271-020, Brazil

5 Departamento de Biologia Aplicada à Agropecuária, Universidade Estadual Paulista "Júlio de Mesquita Filho", Via de Acesso Prof. Paulo Donato Castellane s/n, Jaboticabal, SP 14884-900, Brazil

6 Laboratório de Biologia Estrutural, Instituto Oswaldo Cruz, Fundao Oswaldo Cruz, Avenida Brasil, 4365 Manguinhos, Rio de Janeiro, RJ 21045-900, Brazil continent [7-9, 13, 14, 16, 22, 23]. Acanthocephalans of wild Brazilian mammals have been studied mainly by Travassos [18-21] and Machado-Filho [12, 13], who described six species belonging to Pachysentis, five of these being reported in Brazil by Machado-Filho [13] and Vieira et al. [23]. These species are (1) Pachysentis gethi [13] [17] [syn. Prosthenorchis gethi [13] from Eira barbara (Linnaeus, 1758) (Carnivora, Mustelidae) in Pará and Rio de Janeiro States and from Galictis cuja (Molina, 1782) and G. vittata (Schreber, 1776) in Rio de Janeiro [13, 16, 23]; (2) Pachysentis procyonis [13] [17] [syn. Prosthenorchis procyonis [13] from Procyon cancrivorus (Cuvier, 1798) (Carnivora, Procyonidae) in Rio de Janeiro State [13]; (3) Pachysentis rugosus [13] [17] [syn. Prosthenorchis rugosus [13] from Sapajus cay (Illiger, 1815) (Primates, Cebidae) in Rio de Janeiro State; (4) Pachysentis septemserialis [13] [17] [syn. Prosthenorchis septemserialis [13] from Saguinus niger (Hoffmannsegg, 1807) (Primates, Callitrichidae) in the Pará State [13]; Correa et al. [7]; (5) Pachysentis lenti [13] [17] [syn. Prosthenorchis lenti [13] from Callithrix geoffroyi (Humboldt, 1812) (Primates, Callitrichidae) in Espírito Santo State.

The brown-nosed coati Nasua nasua (Linnaeus, 1766) Storr, 1780 (Procyonidae) is a medium-sized carnivore 

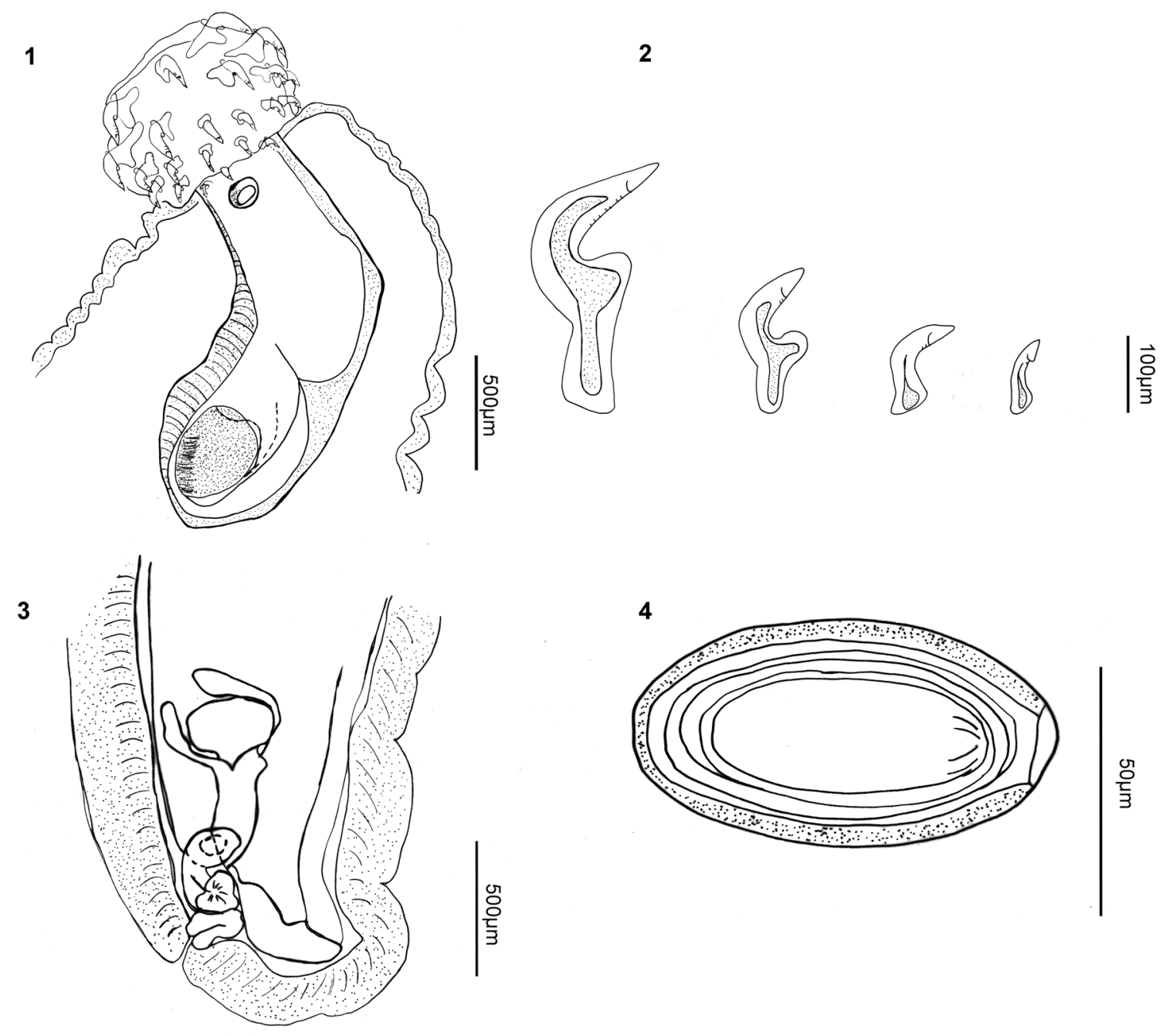

5

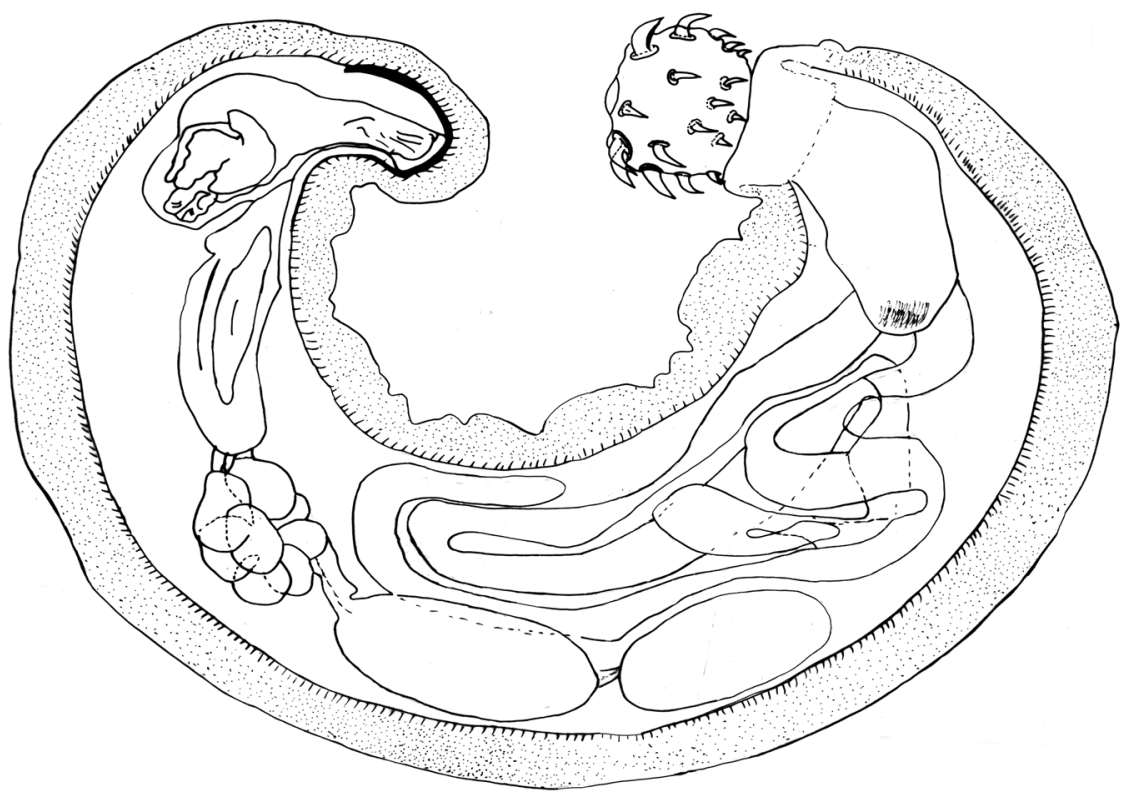

$\frac{\overrightarrow{0}}{\frac{1}{3}}$ 
4Fig. 1-5 Line drawing of Pachysentis lauroi n. sp. collected in the intestine of Nasua nasua from the Brazilian Pantanal Wetlands, Mato Grosso do Sul State. 1—globular proboscis with hooks and proboscis receptacle with cephalic ganglion in proximal region; 2-row with four hooks, apical hooks with double root and proximal hooks with simple root; 3 - posterior region of female showing the vagina, uterus and uterine bell; 4 - ellipsoidal egg with three layers; 5-adult male showing two testes, "clustered" cements glands, ejaculatory ducts and retracted copulatory bursa

abundant in many regions of South America [1, 5], especially in the Pantanal wetlands region $[4,5]$. A few species of acanthocephalans have been reported infecting $N$. nasua, including Oncicola luehei $[19,17]$ in Pará, São Paulo, Minas Gerais, Mato Grosso, and Mato Grosso do Sul States [11, 13, 19, 23] and Neoncicola potosi $[13,17]$ in Foz de Iguaçú, Paraná State [15].

In this study, a new species, Pachysentis lauroi n. sp. is described using light microscopy and scanning electron microscopy (SEM) from the brown-nosed coati in the Brazilian Pantanal wetlands.

\section{Materials and Methods}

Two adult brown-nosed coatis were found between 2007 and 2008 at the Nhumirin Ranch (18 $\left.59^{\prime} \mathrm{S}, 56^{\circ} 39^{\prime} \mathrm{W}\right)$, a research station of the Brazilian Agricultural Research Corporation (Embrapa/Pantanal) in the Nhecolândia subregion of the Pantanal, Mato Grosso do Sul State in the Brazilian Pantanal wetlands. The animals were collected during a research project investigating the ecology and health of wild carnivores. This research project included an inventory of helminth endoparasites. Acanthocephalan specimens were made available to parasitologists at the Oswaldo Cruz Foundation in Rio de Janeiro (FIOCRUZ/RJ). Animal procedures approved by the Brazilian Federal Environmental Agency (IBAMA, first license \#183/2005, CGFAU/LIC; last license \#11772-2) were followed.

The animals were necropsied and acanthocephalan specimens were collected from the small intestine of each individual host and stored in AFA (alcohol + formalin + acetic acid) for $24 \mathrm{~h}$ and stored in $70 \%$ alcohol. Worms used for microscopical studies were stained with acid (hydrochloric) carmine, dehydrated in a graded ethanol series, cleared in phenol $90 \%$ and mounted in Canada balsam (modified from [2], examined using an Axion Scope A1Light Microscope (Zeiss,Göttingen, Germany), and illustrated with the aid of a drawing tube attached to a Zeiss standard 20 light microscope (Zeiss, Göttingen, Germany).

Generic identification was based on the taxonomic key proposed by Schmidt [17] and specific taxonomic descriptions. The description of the new species of Pachysentis was based on 11 specimens (six males and five females).
Measurements are in millimeters unless otherwise stated. The range was followed by the mean in parentheses. Proboscis hooks were counted in longitudinal alternating rows; hooks were measured in terms of its total length: from basal region of hook to the tip, length of the root, and were measured hook + root (tip of the hook to base of the root). The accepted species of Pachysentis deposited in the Coleção Helmintológica do Instituto Oswaldo CruzCHIOC (Helminthological Collection of the Oswaldo Cruz Institute), P.gethi [13, 17] (CHIOC 15680, 17836 a, 17837 b-d, 17838 a-b, 17846, 17852, 38100), P.rugosus [13, 17] (CHIOC 17827, 17828 b-c, 17848), P.procyonis [13, 17] (CHIOC 17847, 17833 a-b, 17854), P.septemserialis [13, 17] (CHIOC 10593, 17812 a-b), P.lenti [13, 17] (CHIOC 14830, 17819 a, 17820 a-c) and species deposited in the Museum für Naturkunde, Berlin, P.procubens [14] (No. 2440, 2443, 2474, 6032), P.ehrenbergi [14] (N²426, 2432, 6033), P.canicola [14] (No. 2571) were used for comparison. Specimens of Pachysentis lauroi n. sp were deposited in the Helminthological Collection of the Institute Oswaldo Cruz (CHIOC), Rio de Janeiro, Brazil, under the number CHIOC no. 38565 a (holotype) and 38565 b (allotype).

For SEM, the specimens were fixed for $1 \mathrm{~h}$ at room temperature in $2.5 \%$ glutaraldehyde in $0.1 \mathrm{M} \mathrm{Na-cacodylate}$ buffer, washed in the same buffer and post-fixed for $3 \mathrm{~h}$ at room temperature in $1 \%$ osmium tetroxide in $0.1 \mathrm{M} \mathrm{Na-caco-}$ dylate buffer. The material was then dehydrated in ascending ethanol series, critical point dried with $\mathrm{CO}_{2}$, mounted with silver cello tape on aluminum stubs, and sputter coated with a 20-nm-thick layer of gold. Samples were examined using a Jeol JSM-6390 LV microscope (JEOL, Akishima, Tokyo, Japan) at an accelerating voltage of $15 \mathrm{kV}$ at the Electron Microscopy Platform of the Oswaldo Cruz Institute.

\section{Results}

\section{Description}

Order Oligacanthorhynchida Petrochenko, 1956

Family Oligacanthorhynchidae Southwell et Macfie, 1925

Pachysentis lauroi n. sp. (Figures 1-11)

General With characters of Pachysentis is designated by Schmidt [17]. Trunk wider anteriorly. Proboscis subspherical with 12 longitudinal rows of four hooks each, totaling 48 hooks (Figs. 1, 2). Proboscis hooks similar in size and shape in both sexes. Apical hooks (types I and II) large with posterior curvature, complex manubria and double roots expanding laterally (Fig. 2). Proximal rows with short hooks (types III and IV) and simple discoid roots 
(Fig. 2). Measurements of length of apical and proximal hooks: length of hook $\times$ length of root and [length from proximal extremity to distal extremity in parentheses] in micrometers: (I) 150-229 (182)×142-203 (170) [197-207 (249)]; (II) 97-145 (115) ×58-113 (81) [126-184 (153)]; (III) 45-118 (70) ×21-53 (39) [61-129 (91)]; (IV) 26-87 $(53) \times 18-39(27)$ [39-103 (63)]. Hooks with terminal barbs visible by light microscopy in all types of hooks (Figs. 2, $8,9,10)$. Base of proboscis surrounded by lateral papillae with elevated border and central pore (Figs. 1, 6, 7); single apical papilla present with elevated border and salient tip at center (Fig. 6, insert). No marked neck. Proboscis receptacle similar in shape and size in both sexes, with two subregions measuring $0.87-1.33(1.16) \times 0.43-0.56(0.47)$, with
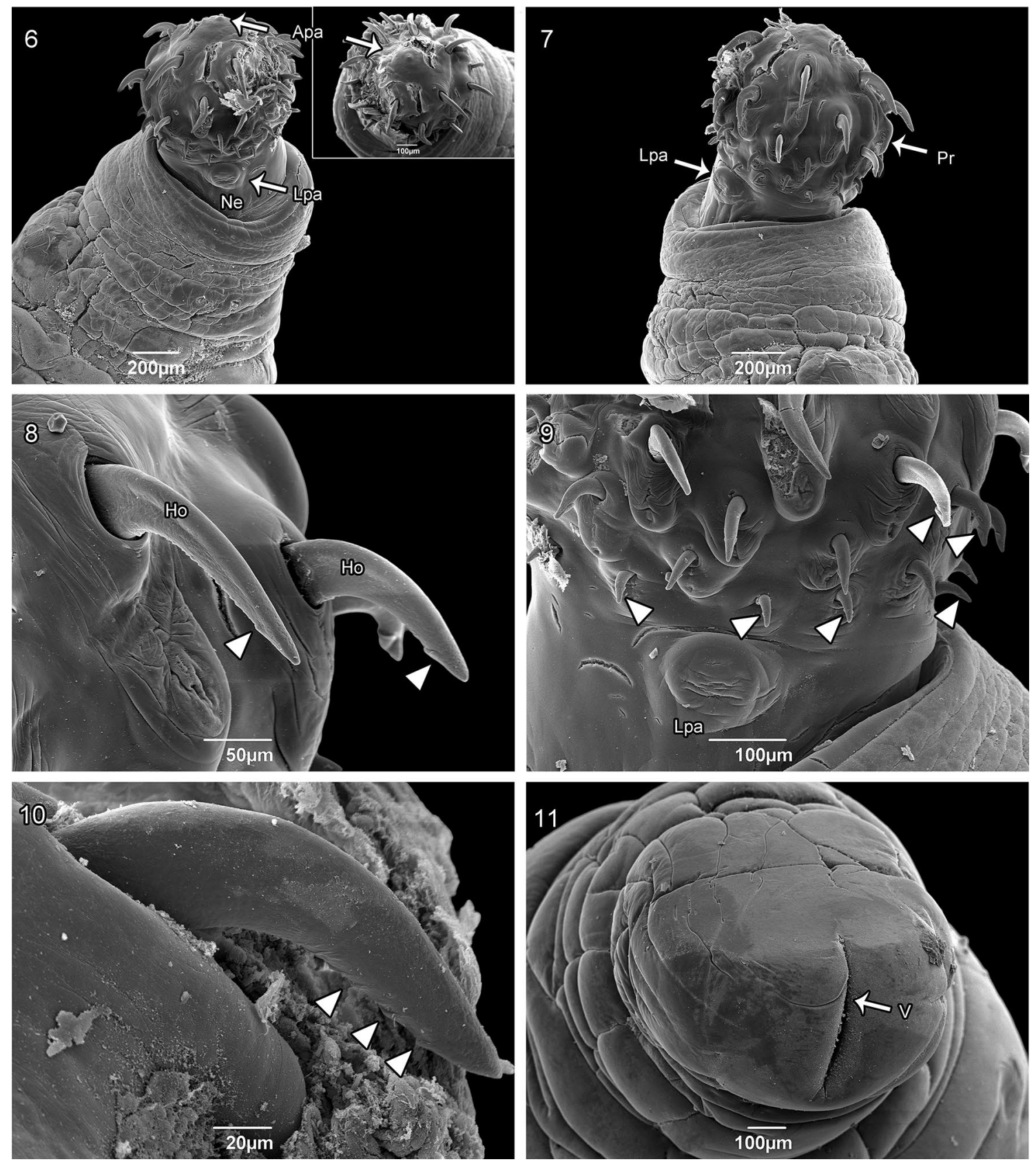

Fig. 6-11 Scanning electron micrographs of specimens of Pachysentis lenti from Nasua nasua in the Brazilian Pantanal Wetlands, Mato Grosso do Sul State. 6 and 7-globular proboscis with lateral papillae and apical papilla; 8 and 9 -apical and proximal hooks at base of the proboscis with barbs on the tips of the hooks (arrowhead); 10 -detail of the barbs on the tip of the apical hooks (arrowhead); 11-posterior end of female body with subterminal vagina. Lpa lateral papillae, Apa apical papilla, $N e$ neck, $\operatorname{Pr}$ proboscis, $H o$ hook, $V$ vagina 
cephalic ganglion region (Fig. 1). Lemnisci long, flattened and curved (Fig. 5).

Males (based on six specimens): Trunk 6.00-16.61 $(9.63) \times 1.53-2.53(1.91)$ wide anteriorly (Fig. 5). Proboscis $0.51-0.73(0.64) \times 0.68-0.85(0.73)$ wide. Lemnisci 4.75-6.83 (5.60), reaching middle of trunk (Fig. 5). Reproductive system in posterior $2 / 3$ of trunk. Testes almost equatorial, contiguous, ellipsoid, in tandem (Fig. 5). Anterior testis $0.85-1.76(1.15) \times 0.32-0.62(0.48)$; posterior testis $0.90-1.90(1.27) \times 0.48-0.60(0.55)($ Fig. 5) . Eight compact uninucleate cement glands, $0.72-1.22$ $(0.86) \times 0.44-0.68(0.56)$. Ejaculatory duct $1.10-2.13$ (1.42). Copulatory bursa terminal, retracted in all specimens (Fig. 5).

Females (based on five specimens): Trunk 10.79-12.95 $(12.07) \times 0.53-2.45(1.62)$ anteriorly. Proboscis $0.53-0.87$ $(0.73) \times 0.68-0.83(0.78)$. Lemnisci 3.30 long in 1 specimen; others masked by eggs. Gonopore subterminal (Fig. 3). Vagina 0.16-0.21 (0.19) long (Figs. 3, 11); uterus 0.61-0.96 $(0.80)$; uterine bell $0.23-0.38(0.31) \times 0.29-0.32(0.30)$ $(n=2)$ (Fig. 3). Total reproductive system 1.11-1.34 (1.19) $(n=3)$. Eggs ellipsoidal, with sculptured outer membrane, $0.064-0.082(0.073) \times 0.054-0.036(0.045)(n=29)($ Fig. 4)

\section{Taxonomic Summary}

Type host: Nasua nasua (Linnaeus, 1766) Storr, 1780 (brown-nosed coati).

Type locality: Nhumirim Ranch (18 $85^{\prime} 90 \mathrm{~S}$, $56^{\circ} 83^{\prime} 90 \mathrm{~W}$ ), Mato Grosso do Sul State, Brazil.

Site of infection: Small intestine.

Etymology: The new species is named in honour of Dr. Lauro Travassos, who contributed greatly to our knowledge of the Brazilian Acanthocephala.

\section{Remarks}

In this study, we identified the specimens obtained from Nasua nasua (Linnaeus, 1766) Storr, 1780 as belonging to the Oligacanthorhynchidae and Pachysentis due to the presence of a subspherical proboscis, anterior trunk wider than posterior, proboscis with 48 hooks in 12 longitudinal rows of four hooks each using [17]. In addition, Machado-Filho [13] considered the number of hooks on the proboscis and the size of the testes as the best characteristics for identifying and distinguishing species of the genus. Pachysentis lauroi n. sp. is compared with the other valid species of Pachysentis in Table 1 and further distinguished in the dichotomous key presented below.

\section{The Status of Pachysentis septemserialis [13]}

The specimens from CHIOC (17812 a-b and 10593) were carefully studied and it was observed that they exhibited some morphological characters not mentioned in the original description. The paratype (permanent slides CHIOC 17812 a-b) was not informative regarding the number of hooks, and a collar was observed at the base of the proboscis, suggesting affiliation with the genus Prosthenorchis [18]. The female paratype from CHIOC 10593 has 12 longitudinal rows of four hooks with total of 48 hooks, which contradicts the number of the hooks given in the original description (seven rows of seven hooks, total 49 hooks) with no collar at the base of the proboscis [13]. Additionally, there is a lack of some information on this species, such as the taxonomic and morphometric characters of adult males. Therefore, we suggest that the specimens designated as $P$. septemserialis $[13,17]$ may be synonymous with $P$. lenti $[13,17]$, as to the number of the hooks, other morphometric characteristics and the fact that both are parasites of primates of the family Callitrichidae. The taxonomy of this species needs to be revised.

\section{The Status of Pachysentis ehrenbergi [14]}

Specimens of Pachysentis ehrenbergi deposited in the Museum für Naturkunde from Vulpes vulpes (No. 2426) and Naja haje (No. 2432, 6033) were also examined. Specimens from both hosts had barbs on the tip of all hooks, which was not mentioned by Meyer [14] in the original description. Other morphological characteristics, such as the number of hooks, short neck, the presence and size of nuclei in the leminisci and the reproductive organs agree with the original description.

Pachysentis lauroi $\mathrm{n}$. sp. distinguished from the other species of Pachysentis by a combination of morphological characters, including the number of the hooks in each longitudinal row, the presence of barbs on the hooks and the arrangement of the cement glands (Table 1). The following key and Table 1 do not include $P$. septemserialis, because of its uncertain taxonomic status, but enable the new taxon to be distinguished from the other nine recognized species of the genus.

1. Proboscis with 12 longitudinal rows, alternating or not, of 3-4 hooks each.....................................................2

-Proboscis with 12 alternating longitudinal rows of

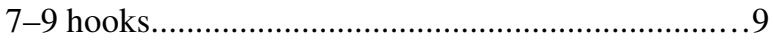

2. Proboscis with a total of $42-48$ hooks......................... 3 -Proboscis with a total of 72 hooks................ canicola [14]

3. Proboscis with a total of 42 hooks................................ 4 -Proboscis with a total of 48 hooks..........................................

4. Cement glands in pairs..................................................6 -Cement glands clustered.................................................... 


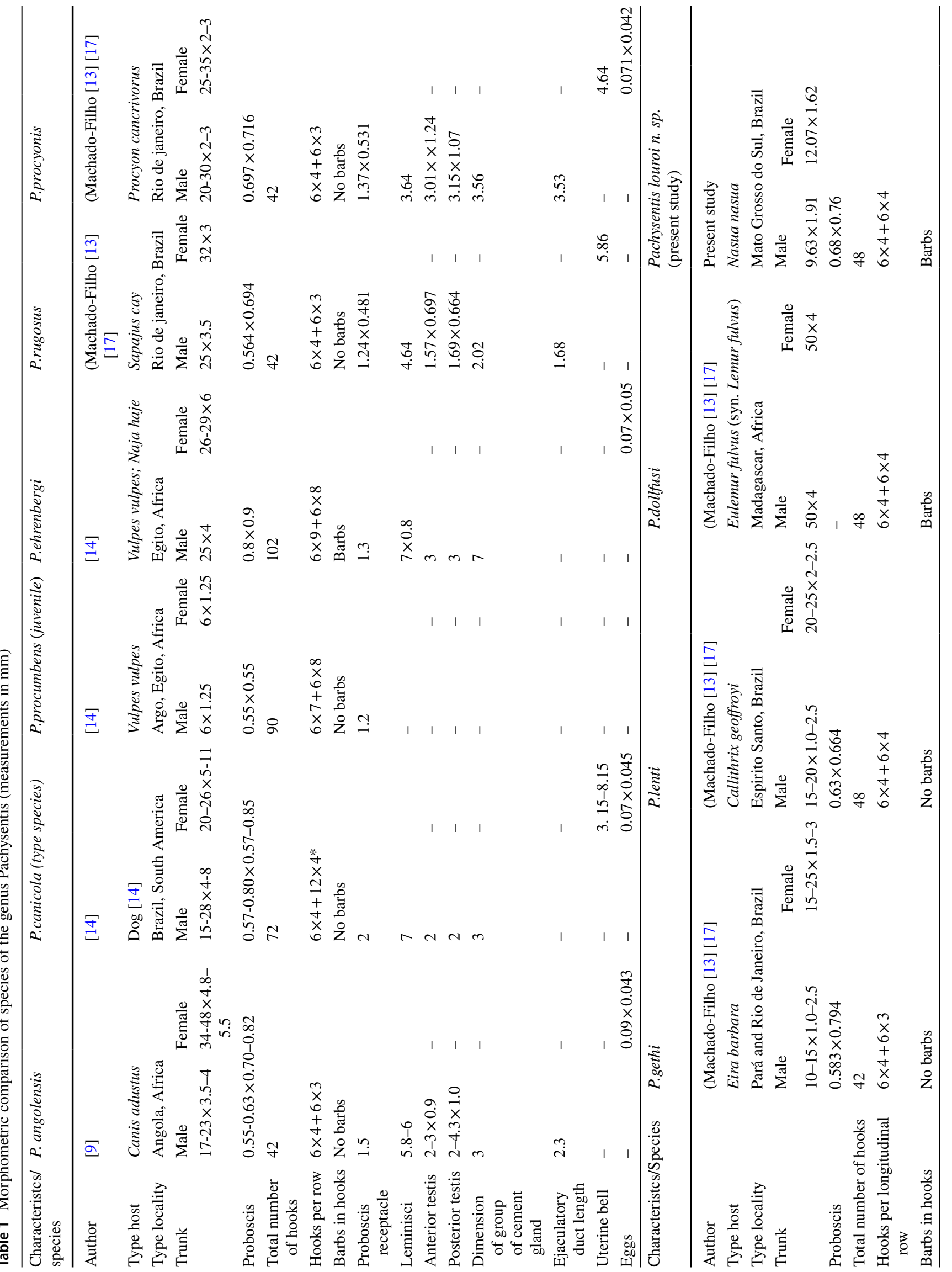




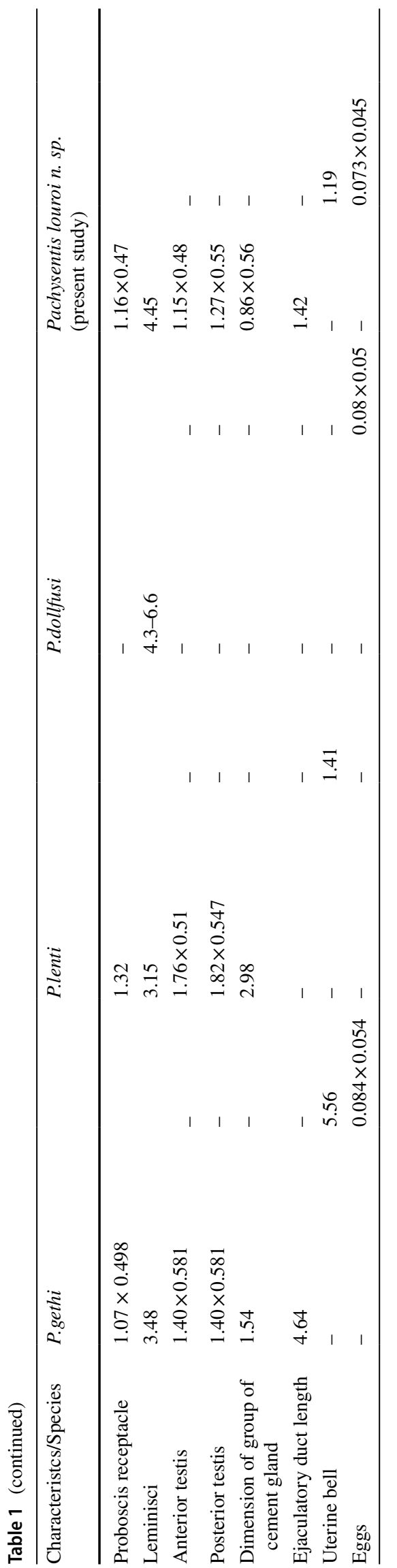

5. Hooks with visible barbs ("arrow-shaped hook tip")...8 -Hooks without barbs. P. lenti [13] [17]

6. Parasite of carnivores in Africa...P. angolensis [9] [17] -Parasite of carnivores in the Americas

P. gethi [13] [17]

7. Very short lemnisci not reaching anterior testis. Parasites of carnivores .P. procyonis [13] Schmidt, [17] -Leminisci reaching anterior testis. Parasites of primates P. rugosus [13] Schmidt, [17]

8. Cement glands in pairs ...P. dollfusi [13] Schmidt, [17] -Cement glands in clusters.............. lauroi $\mathrm{n} . \mathrm{sp}$.

9. Proboscis $0.55 \mathrm{~mm}$ wide, with a total of 90 hooks without barbs P. procumbens [14]

-Proboscis $0.8-0.9 \mathrm{~mm}$ wide, with a total of 102 hooks with barbs P. ehenbergi [14]

Pachysentis lauroi n. sp. is further distinguished from P. angolesis, $P$. canicola, $P$. procumbens, $P$. ehrenbergi, $P$. gethi, $P$. procyonis and $P$. rugosus by the number of hooks in each row, with 12 longitudinal rows of four hooks each, totaling 48 hooks (Table 1). Our specimens were similar to $P$. lenti and $P$. dollfusi in the number of hooks (48) on the proboscis. The new species can, however, be distinguished from $P$. lenti by having barbs on all hooks and from $P$. dollfusi by the organization of the cement glands (in cluster vs in uniform pairs), the size of trunk and the definitive host (Table 1). In addition, when Machado-Filho [13] described $P$. dollfusi, he indicated that this acanthocephalan infected a zoo animal in Brazil and that is native of Madagascar. Golvan [10], however, warned that the origin of this species might not have been Madagascar. Nevertheless, it is not known whether the species originates in Brazil or Madagascar.

\section{Discussion}

Meyer [14] proposed Pachysentis with the type species P.canicola [14] from a domestic dog in Brazil. The same species was found infecting a gray fox Urocyon cinereoargenteus (Schreber, 1775) (Carnivora: Canidae) in the United States [6]. Two additional species, P. ehrenbergi [14] and $P$. procumbens Meyer, [14], were described from Vulpes vulpes (Linnaeus, 1758) in Egypt [14, 22], suggesting that species from this genus are parasites of carnivores (Order Carnivora).

Van Cleave [22] also studied acanthocephalan parasites from North American mammals and recorded $P$. canicola in the gray fox and the skunks Mephitis mephitis mesomelas (Lichtenstein, 1832), Conepatus leuconotus (Lichtenstein, 1832) and Spilogale gracilis leucoparia (Merriam, 1890), and recognized the three previous species of the genus. Yamaguti [24] revised the classification of the 
Acanthocephala and considered their geographic distributions, revised the diagnosis of the genus Pachysentis and followed the classification of Meyer [14] and Van Cleave [22] with three species in the genus.

Schmidt [17] revised the family Oligacanthorhynchidae and transferred six species of Prosthenorchis [18] to the genus Pachysentis, i.e., P. dollfusi, P. gethi, P. lenti, P. procyonis, $P$. rugosus, $P$. septemserialis and $P$. angolensis [syn. Oncicola angolensis [9]. Pachysentis [14] then included a total of 10 species based on morphological features, such as an anterior trunk wider than the posterior trunk; the absence of a festooned collar; a globular proboscis with 12 longitudinal rows of 3-12 hooks, totaling 42-102 hooks; larger anterior hooks with complex manubria and roots, as well as rootless posterior hooks; tips of the hooks with or without barbs; long and flattened lemnisci arranged a band; testes in tandem in the mid-trunk; eight compacted cement glands; and oval eggs with sculptured outer membranes (Yamaguti $[17,24]$.

According to this classification, the type hosts for species of Pachysentis are primates and carnivores with geographic distributions restricted to Africa and North, Central and South America [7-9, 13, 14, 16, 22, 23]. In the revisions by Golvan [10] and Amin [3], the authors updated the classification of the Acanthocephala and considered Pachysentis as including 10 valid species described by Meyer [14], Golvan [9] and Machado-Filho [13]. Therefore, the member species are $P$. canicola, $P$. ehrenbergi, $P$. procumbens, $P$. angolensis, $P$. dollfusi, $P$. gethi, $P$. lenti, $P$. procyonis, $P$. rugosus and $P$. septemserialis.

Our study provides details of Pachysentis lauroi $n$. $s p$. by scanning electron microscopy showing the presence of barbs on hooks in the proboscis, and the apical and lateral papillae-like structure on the proboscis, as morphological character to identify the new species. Furthermore, we are adding new information of morphology of two species, $P$. septemserialis and Pachysentis ehrenbergi and their status in the genus. Finally, we report a new definitive host in a new geographical area for the Pachysentis genus.

\footnotetext{
Acknowledgements We are grateful to Ricardo Baptista Schimidt from the image processing and treatment service of the Institute of Oswaldo Cruz (FIOCRUZ); the curator of the Helminthological Collection of the Institute of Oswaldo Cruz, Dr. Marcelo Knoff, and the curator of the Worms collection in the Museum für Naturkunde, Dr. Birger Neuhaus, for both making available the specimens from their collections; and the staff of the Empresa Brasileira de Pesquisa Agropecuária/Pantanal (Embrapa) for their assistance with the field work. Funds were provided by the Conselho Nacional de Desenvolvimento Científico e Tecnológico (no. 484501/2006-2) and the University of Missouri. We thank the Post-Graduate Program in Parasite Biology of the Instituto of Oswaldo Cruz (PGBP/IOC/Fiocruz) and the Institute of Oswaldo Cruz (IOC/Fiocruz) and Fundação Carlos Chagas Filho de Amparo à Pesquisa do Estado do Rio de Janeiro (FAPERJ) for financial support (Grant nos E-26/201.961/2017). This study received financial support from CAPES, IOC-Fiocruz and FAPERJ.
}

Open Access This article is distributed under the terms of the Creative Commons Attribution 4.0 International License (http://creativeco mmons.org/licenses/by/4.0/), which permits unrestricted use, distribution, and reproduction in any medium, provided you give appropriate credit to the original author(s) and the source, provide a link to the Creative Commons license, and indicate if changes were made.

\section{References}

1. Alho CJR, Lacher JTE, Campos ZMS, Gonçalves HC (1987) Mamíferos da Fazenda Nhumirim, sub-região de Nhecolândia, Pantanal do Mato Grosso do Sul: I-levantamento preliminar de espécies. Revista Brasileira de Zoologia 4:151-164. https://doi. org/10.1590/S0101-81751987000200007

2. Amato J.F.R. 1985. Manual de Técnicas para a Preparação de Coleções Zoológicas. 8. Platelmintos (temnocefálidos, trematódeos, cestóides, cestodários) e acantocéfalos. Sociedade Brasileira de Zoologia, São Paulo, Brazil

3. Amin OM (2013) Classification of the Acanthocephala. Folia Parasitol 60:273-305. https://doi.org/10.14411/fp.2013.031

4. Bianchi RC, Campos RC, Xavier Filho NL, Olifiers N, Gompper ME, Mourão GM (2014) Intraspecific, interspecific, and seasonal differences in the diet of three mid-sized carnivores in a large neotropical wetland. Acta Theriologica 59:13-23. https://doi. org/10.1007/s13364-013-0137-x

5. Bianchi RC, Olifiers N, Gompper ME, Mourão GM (2016) Niche Partitioning among Mesocarnivores in a Brazilian Wetland. PLoS One 11:e0162893. https://doi.org/10.1371/journal.pone.0162893

6. Buechner HK (1944) Helminth parasites of the gray fox. J Mammal 25:185-188. https://doi.org/10.2307/1375019

7. Corrêa P, Bueno C, Soares R, Vieira FM, Muniz-Pereira LC (2016) Checklist of helminth parasites of wild primates from Brazil. Revista Mexicana de Biodiversidad 87:908-918. https:// doi.org/10.1016/j.rmb.2016.03.008

8. García-Prieto L, Falcón-Ordaz J, Guzmán-Cornejo C (2012) Helminth parasites of wild Mexican mammals: list of species, hosts and geographical distribution. Zootaxa 3290:1-92

9. Golvan YJ (1957) Acanthocéphales de l'Angola. I. Oncicola angolensis n. sp. (Archiacanthocephala, Pachysentidae), parasite du chacal Canis adustus Sundevall. Publicacion Servicos Culturais de la Companhia de Diamantes de Angola, Museo do Dundo 34:39-50

10. Golvan YJ (1994) Nomenclature of the Acanthocephala. Res Rev Parasitol 54:134-205

11. Lent H, Freitas JFT (1938) Pesquisas helminthologicas realisadas no estado do Pará. VI. Acanthocephala. Memórias do Instituto Oswaldo Cruz 33:455-459

12. Machado-Filho DA (1940) Pesquisas helmintológicas realizadas no estado de Mato Grosso-Acanthocephala. Memórias do Instituto Oswaldo Cruz 35:593-601

13. Machado-Filho DA (1950) Revisão do gênero Prosthenorchis Travassos, 1915 (Acanthocephala). Memórias do Instituto Oswaldo Cruz 48:495-544

14. Meyer A (1931) Neue Acanthocephalen aus dem Berliner Museum. Burgründung eines neuen Acanthocephale Systems auf Grund einer Untersuchung der Berliner Sammlung. Zoologische Jahrbücher Abteilung für Systematik, Ökologie und Geographie der Tiere 62:53-108

15. Moraes MFD (2016) Estudos parasitológicos em cães domésticos errantes e carnívoros selvagens generalistas no Parque Nacional do Iguaçu, Foz do Iguaçu. Dissertation, Universidade Estadual Paulista, Jaboticabal, Brazil

16. Muniz-Pereira LC, Corrêa P, Bueno C, Vieira FM (2016) Rediscovery of Pachysentis gethi (Acanthocephala: 
oligacanthorhynchidae), a parasite of wild lesser grison Galictis cuja (Carnivora: Mustelidae) from Brazil. Revista Mexicana de Biodiversidad 87:1356-1359. https://doi.org/10.1016/j. rmb.2016.10.0101870-3453

17. Schmidt GD (1972) Revision of the class Archiacanthocephala Meyer, 1931 (Phylum Acanthocephala), with emphasis on Oliganthorhynchidae Southwell et Macfie, 1925. J Parasitol 58:290-297

18. Travassos L (1915) Revisão dos Acanthocephalos brasileiros. I. Fam. Gigantorthynchidae Hamann, 1982 (Nota prévia). Brasil Médico 29:105

19. Travassos L (1917) Contribuição para o conhecimento da fauna helmintológica brasileira, XVII. Revisão dos acantocéfalos brasileiros. Parte I. Fam. Gigantorhynchidae Hamann, 1982. Memórias do Instituto Oswaldo Cruz 9:5-62

20. Travassos L (1926) Contribuições para o conhecimento da fauna helmintológica brazileira. XX. Revisão dos acanthocephalos brazileiros. Parte 11. Familia Echinorhynchidae Hamann, 1892, sub-fam. Centrorhynchinae Travassos, 1919. Memórias do Instituto Oswaldo Cruz 19:31-125

21. Travassos L, Pinto C, Muniz J (1927) Excursão scientifica ao Estado de Mato Grosso na Zona do Pantanal (margens dos rios S. Lourenço e Cuyabá) realizada em 1922. Memórias do Instituto Oswaldo Cruz 20:249-269

22. Van Cleave HJ (1953) Acanthocephala of North American mammals. Ill Biol Monogr 23:1-79

23. Vieira FM, Luque JL, Muniz-Pereira LC (2008) Checklist of helminth parasites in wild carnivore mammals from Brazil. Zootaxa 1721:1-23. https://doi.org/10.5281/zenodo.181136

24. Yamaguti S (1963) Systema Helminthum, vol 5. Acanthocephala. Wiley, New York, pp 423

Publisher's Note Springer Nature remains neutral with regard to jurisdictional claims in published maps and institutional affiliations. 